\title{
TRÊS CONTRIBUIÇÕES PARA A HISTÓRIA ECONÔMICA MEDIEVAL
}

\author{
TRES CONTRIBUCIONES A LA HISTORIA ECONÓMICA MEDIEVAL
}

\section{THREE CONTRIBUTIONS TO MEDIEVAL ECONOMIC HISTORY}

DOI: http://dx.doi.org/10.9771/gmed.v12i3.42926

Ligia Maria Osório Silva ${ }^{1}$

\begin{abstract}
Resumo: Estudioso da história da Alemanha, com a atenção principal voltada para a organização dos trabalhadores, visando a transformação revolucionária, Engels fez importantes contribuições às circunstâncias do seu passado histórico. Em “A Guerra dos Camponeses Alemães” (1850), do século XVI e "A Marca” (de 1882), Engels dedica-se às lutas camponesas e como a transformação das formas de apropriação, com a introdução da propriedade privada plena na fase final do feudalismo levou a uma melhor compreensão das mudanças decorrentes na organização social que tiveram um papel fundamental na diversificação do campesinato e na formação das classes sociais no capitalismo.
\end{abstract}

Palavras- chave: Contribuições. Lutas camponesas. Transfomações.

Resumen: Un estudioso de la historia de Alemania, con su enfoque principal en la organización de los trabajadores, con el objetivo de la transformación revolucionaria, Engels hizo importantes contribuciones a las circunstancias de su pasado histórico. En "La guerra de los campesinos alemanes" (1850), del siglo XVI y "La marca" (de 1882), Engels se dedicó a las luchas campesinas y a cómo transformar formas de apropiación, con la introducción de la propiedad privada plena en el escenario. El fin del feudalismo llevó a una mejor comprensión de los cambios resultantes de la organización social que jugaron un papel fundamental en la diversificación del campesinado y en la formación de clases sociales en el capitalismo.

Palabras clave: Contribuciones. Luchas campesinas. Transformaciones.

Abstract: A scholar of the history of Germany, with his main focus on the organization of workers, aiming at revolutionary transformation, Engels made important contributions to the circumstances of his historical past. In "The German Peasants' War" (1850), from the 16th century and "The Brand" (from 1882), Engels dedicated himself to peasant struggles and how to transform forms of appropriation, with the introduction of full private property at the stage the end of feudalism led to a better understanding of the changes resulting from social organization that played a fundamental role in the diversification of the peasantry and in the formation of social classes in capitalism.

Keywords: Contributions. Peasant struggles. Transformations.

Na vasta obra produzida por Friedrich Engels ao longo da sua vida, as contribuições que deixou para a história econômica ocupam um lugar muito importante. Estudioso da história da Alemanha, com a atenção principal voltada para a organização dos trabalhadores, visando a transformação revolucionária, Engels achava importante esclarecê-los a propósito das circunstâncias do seu passado histórico para que agissem com eficiência na política no presente. Para levar adiante esse objetivo ele se voltou para a análise de períodos críticos que tiveram efeitos de longa duração na organização econômica e social dos povos de língua alemã, trazendo com isso grandes aportes aos estudos dos sistemas econômicos. Neste texto vamos tratar brevemente de três contribuições maiores que emanaram das suas análises. 
A primeira contribuição, decorreu do seu estudo sobre as lutas camponesas. O movimento desenrolou-se no começo do século XVI, e consistiu na Reforma Protestante e seu desdobramento, a revolução antifeudal da Guerra dos Camponeses. O movimento, que começou em 1522-23, foi protagonizado inicialmente pela baixa nobreza que lutava contra os altos encargos pagos aos príncipes. A conflagração surgiu na esteira das questões abertas pela Reforma contra a Igreja romana, mas a partir de determinado momento fugiu ao controle da pequena nobreza, dos comerciantes e do próprio Lutero e assumiu as características de um levante popular radical. Foi o momento em que Thomas Müntzer teve um papel preponderante. Os embates tornaram-se particularmente violentos em regiões do sul da Alemanha, Suábia, Turíngia, Tirol, e em localidades alpinas e partes do vale do rio Reno. Em 1848, isto é, dois anos antes de se debruçar sobre esse tema, Engels participara da Revolução de 1848 no Palatinado (estado situado na região sudoeste da atual Alemanha) que envolvera a burguesia, os camponeses e os trabalhadores das cidades na luta pela implementação de um programa progressista visando a unificação dos estados alemães numa República. Após a derrota do movimento, durante seu exílio, Engels procurou refletir sobre as razões do fracasso da revolução e pareceu-lhe apropriado fazer um paralelo entre os acontecimentos de 1848 e a grande revolução camponesa do século XVI. ${ }^{2}$

Em 1850, portanto, Engels publicou na Nova Gazeta Renana, números 5 e 6, A Guerra dos Camponeses Alemães, ${ }^{3}$ um trabalho que procurava explicar as razões que levaram camponeses e segmentos da população pobre das cidades de várias regiões de fala alemã, entre os anos de 1524 a 1526, a se revoltarem contra a situação de miséria e opressão na qual se encontravam. Fez um estudo detalhado do levante com o intuito de ir além da forma externa dos eventos políticos e compreender as forças econômicas por trás dos fatos. Esperava contribuir assim para lançar luz, também, sobre a derrota de 1848 e o papel que a burguesia desempenhara nas duas revoluções. Uma das conclusões a que chega é que os mesmos erros que provocaram a derrota das insurreições camponesas também ocasionaram a derrota em 1848, esses erros levaram à defecção da burguesia.

$\mathrm{Na}$ sua análise Engels considera que a guerra dos camponeses fora uma primeira tentativa de pôr fim ao regime feudal e fracassara devido às hesitações da burguesia. Em meio às questões religiosas tinham lugar as reivindicações das diversas camadas sociais. $O$ capitalismo estava nos seus primórdios, a burguesia era uma classe em formação que ainda não adquirira uma consciência clara dos seus interesses de classe e de quem eram seus aliados naturais, prisioneira ainda, portanto, da ideologia feudal. A plebe das cidades e o campesinato que suportavam todo o peso do edifício social também não eram conscientes dos seus interesses específicos e esgotavam-se nas ações espontâneas, pilhando conventos e incendiando castelos. Causavam pânico por onde passavam, eram divididos pelos interesses locais e eram enganados facilmente pelos seus adversários. As 
palavras de ordem dos camponeses condensadas nos "12 artigos" ${ }^{4}$ constituíam na realidade a expressão radical de uma outra revolução que ainda procurava o seu caminho: os camponeses, pelas suas ações, seriam os pioneiros da revolução burguesa, os anunciadores do fim necessário do regime feudal. ${ }^{5}$

$\mathrm{Na}$ sua abordagem inovadora, tratava-se menos de analisar o papel dos grandes nomes da Reforma do que de revelar os interesses de classes que eles representavam. Considerava que, embora as lutas religiosas tivessem sido a motivação inicial, o comportamento das partes envolvidas no conflito assumira um caráter de classe cada vez mais acentuado, sendo a primeira expressão histórica da luta da burguesia para a tomada do poder. Engels chega mesmo a considerar que, a revolução camponesa do século XVI fora precursora das revoluções burguesas bem-sucedidas da Inglaterra (século XVII) e da França (século XVIII).

Por outro lado, também via limites no paralelo que estabelecera entre a revolução de 1848 e a do século XVI:

Quem lucrou com a revolução de 1525? Os príncipes. Quem lucrou com a revolução de 1848? Os grandes soberanos: a Áustria e a Prússia. Por trás dos pequenos príncipes de 1525 havia, ligados a eles pelos pagamentos de impostos, os pequeno-burgueses. Por trás dos grandes príncipes de 1850 , por trás da Áustria e da Prússia, estão os grandes burgueses modernos que os submetem rapidamente através da dívida do Estado. E por trás dos grandes burgueses, está o proletariado. ${ }^{6}$

Thomas Müntzer o líder radical do movimento teve um destino trágico, segundo Engels, porque foi colocado numa situação impossível:

\begin{abstract}
A pior coisa que pode acontecer ao líder de um partido extremista, é ele ser obrigado a assumir o governo em um momento em que o movimento político não está suficientemente desenvolvido para manter no poder a classe que ele representa, ou aplicar as medidas que a situação exige. [...] Ele se encontra, assim, diante de um dilema insolúvel: aquilo que ele pode fazer é irrealizável. Numa palavra, ele é obrigado, não a representar seu partido e sua classe, mas representar a classe para cuja dominação o movimento está maduro. Ele é obrigado, no interesse de todo o movimento, a realizar os interesses de uma classe que lhe é estranha [...]. Qualquer um que se encontre nessa situação falsa está irremediavelmente perdido. ${ }^{7}$
\end{abstract}

Não se tratando de um trabalho baseado em fontes primárias $^{8}$, evidentemente, deve ser lido com o devido cuidado uma vez que muito se pesquisou e descobriu desde então, inclusive no campo marxista. O próprio Engels, na sua carta a Franz Mehring de julho de 1893, ensaia algumas críticas ao seu trabalho de 40 anos antes. Acredita que pôs ênfase demais nos aspectos econômicos e descurou dos aspectos ideológicos na análise da guerra. A Reforma foi na origem essencialmente uma revolta espiritual contra a dominação da Igreja romana, em consequência, as preocupações religiosas dos homens daquele tempo não podiam ser minimizadas. ${ }^{9}$ Os estudos posteriores sobre Müntzer também lançaram mais luz sobre o personagem, levando Engels a nuançar a ideia de que fosse um revolucionário para considerá-lo mais um reformador. Resta frisar que o trabalho de Engels foi pioneiro na análise das Guerras Camponesas. Foi somente a partir da publicação do seu 
livro que se começou a escrever profusamente sobre o tema, mesmo na Alemanha. ${ }^{10} \mathrm{E}$, mais importante ainda, junto com o texto de Marx da mesma época, As lutas de classe na França, constituiu um dos primeiros ensaios da análise dos processos chamados de "revoluções burguesas", suas fases, seus mecanismos, a dinâmica das classes, a possibilidade ou não de se forjarem alianças de classe etc.

\section{A marca}

Continuando sua militância em prol do avanço do movimento socialista na Alemanha, Engels continuou a produzir trabalhos a propósito da situação dos camponeses com o objetivo de ajudar na formulação de políticas voltadas para esse segmento, políticas que seriam aplicadas pelo Partido Socialdemocrata. As duas outras contribuições para a história econômica para as quais gostaríamos de chamar a atenção estão num estudo feito por Engels, já mais para o final do século. Ele debruçou-se sobre os primórdios da organização social do campo, escrevendo um texto intitulado, A Marca (1882), ${ }^{11}$ que exigiu um esforço considerável: foi refeito três vezes antes de ser entregue para publicação. ${ }^{12}$ Diferentemente das Guerras Camponesas, para escrevê-lo, Engels consultou profusamente as fontes disponíveis à época.

O próprio autor esclareceu no início do artigo as razões de seu interesse por incursionar nesse período histórico: "num país como a Alemanha, onde aproximadamente metade da população vive da agricultura, vale a pena que os operários socialistas e, por intermédio deles, os camponeses, tomem conhecimento da origem da propriedade fundiária atual, pequena ou grande". O resultado foi a elaboração de uma síntese da história agrária alemã, das origens às grandes transformações do século XIX.

O objetivo do estudo era contrastar a antiga forma de apropriação, isto é, a propriedade coletiva do solo, com a moderna propriedade privada que estava trazendo a miséria e a subordinação dos pequenos camponeses endividados de sua época. Havia interesse em resgatar o conhecimento dessas formas de apropriação que estavam se perdendo na memória coletiva. Lidava, portanto, com um fenômeno fundamental na aparição das sociedade modernas: a transformação da noção de propriedade e a desarticulação progressiva do sistema que Marx chamaria de modo de produção feudal, com sua gama de direitos consuetudinários. ${ }^{13}$ Marx havia lidado com esses fatos concretamente, pela primeira vez, em 1842, quando escreveu na Gažta Renana seus artigos sobre a criminalização do roubo de lenha. ${ }^{14} \mathrm{O}$ processo de transformação por que passava o campo e que consistiu basicamente no cercamento das terras comunais e na desapropriação das parcelas camponesas, vinha ocorrendo desde o século XIV em todas as regiões onde dominara o 
feudalismo, mas no século XIX estava bem avançado. Marx tratará do tema n’O Capital ao abordar a questão da acumulação primitiva. ${ }^{15}$

Os historiadores estão, em geral, de acordo ao ver no feudalismo europeu dois sistemas agrários. O primeiro, chamado seigneurie na França, manoir na Inglaterra ou Grundherrschaft na Alemanha, caracterizava-se por uma exploração agrícola constituída de duas frações. Uma, a "reserva" ou "domínio", era explorada pelo senhor com a ajuda de mão de obra de diversas proveniências; a outra fração estava dividida em pequenas explorações camponesas (tenures); seus ocupantes encontravam-se numa situação de subordinação política e social perante os senhores e deviam-lhes obrigações, sendo a principal o pagamento de uma renda na forma de produto ou dinheiro; em contrapartida, gozavam de direitos emanados dos usos e costumes, entre os quais o direito hereditário às suas parcelas de terras. No outro sistema agrário, o Gutsherrschaft, o latifúndio ocupou um lugar central. Nesse sistema, a economia da reserva??? era a exploração agrícola predominante e seu cultivo era garantido pelo trabalho gratuito (corveia) dos camponeses que, em troca, possuíam uma pequena parcela de terra para a sua subsistência. ${ }^{16}$

O estudo de Engels começa justamente lançando uma luz sobre os tempos da formação do sistema feudal (a Alta Idade Média). Originalmente, o termo marca significava, sinal, fronteira ou um território circunscrito (ou delimitado); somente com o passar do tempo passou a significar as terras baldias e a associação que as possuía em regime de propriedade ou usufruto. O termo companheiros da marca, presente nos documentos antigos, designava as pessoas cujas propriedades estavam situadas em volta de, ou confinavam com os terrenos baldios. Neste tipo de associação de camponeses ${ }^{17}$, usuários e detentores de parcelas de terra, a apropriação não pode ser descrita simplesmente como "propriedade comunal" nem, muito menos, como "propriedade privada". A marca reunia uma combinatória de elementos na qual estavam presentes a distribuição comunitária trienal das parcelas de terras a serem cultivadas e seu uso particular pelas famílias camponesas, a definição do que seria plantado em cada faixa de terreno em cada época do ano, a utilização em comum das pastagens, dos bosques e charnecas, e mesmo a atribuição da propriedade privada da casa e do terreno adjacente (ferme, em francês, homestead, em inglês) a que tinham direito alguns camponeses. As normas que regulavam todas essas formas sociais encontravam-se na Constituição de marca, a implementação da sua aplicação (associação da marca propriamente dita) e a distribuição das sanções quando necessárias eram atribuição da Justiça da marca. Esse modelo de organização social, ou formas bem assemelhadas, na Alta Idade Média, podiam ser encontrados também em regiões do Norte da França, na Inglaterra e na Escandinávia. ${ }^{18}$

O surgimento da marca esteve relacionado a dois tipos de fenômenos. Por um lado, a marca seria um dos efeitos ocasionados pela fragmentação da autoridade central quando o poderio 
dos senhores de terra sucedeu ao vazio de poder. Formou-se, ao mesmo tempo, um tipo de comunidade reunindo diversas aldeias que englobavam todos os "vizinhos", inclusive aqueles que não exerciam qualquer profissão especificamente agrária, como ferreiros ou moleiros. Por outro lado, uma das suas funções primordiais era regulamentar e dirigir o processo de utilização dos terrenos baldios cujo cultivo em larga escala foi uma consequência do crescimento demográfico ocorrido nos séculos XII e XIII.

Segundo o historiador Slicher Van Bath, o período em que surgiram tais associações dependeu do acréscimo demográfico e da natureza dos solos. Embora tenham aparecido na Alta Idade Média, na maioria dos países firmaram-se entre o século XI e XIV. O crescimento demográfico registrado nos séculos XII e XIII trouxe como consequência o arroteamento de baldios em larga escala. Reduziram-se assim as possibilidades de criar gado nesses terrenos, ao mesmo tempo em que, para o amanho das terras recém arroteadas se precisava de mais gado, tanto como animais de tiro como produtores de estrume. Quebrara-se o equilíbrio entre a população humana e a animal. E isto não foi apenas consequência do aumento do contingente de gado, mas também da modificação da sua composição. $\mathrm{Na}$ época carolíngia predominava ainda o gado miúdo (ovelhas, porcos, cabras); nos séculos XII e XIII, os cavalos e o gado vacum passaram a ocupar um lugar muito mais significativo. Isto implicou que os terrenos baldios tiveram de ser usados como terrenos de pastagem muito mais intensivamente. Os usuários das terras baldias ou os proprietários das herdades congregaram-se para a defesa dos seus direitos. Esta associação podia ser orientada em dois sentidos: contra os detentores do poder judicial que haviam usurpado o direito da concessão de usufrutos, e contra os pequenos lavradores e jornaleiros que não possuíam quaisquer antigos direitos usufrutuários. ${ }^{19}$

\section{A colonização de novos territórios}

O processo de utilização dos terrenos baldios consistiu também num vasto movimento de ocupação e colonização de terras. No texto Engels descreve as características da colonização, processo que se assemelha bastante com a situação de "fronteira". A peculiaridade dos fenômenos de fronteira foi apontada no final do século XIX por Frederik Jackson Turner para a história da ocupação do Oeste norte-americano. Além de envolver a ocupação de terras consideradas vazias (o que no caso americano e de muitos outros processos de fronteira significou ignorar ou suprimir a presença dos autóctones, mas nem sempre), um dos aspectos marcantes desse processo foi a oferta de relações de trabalho e de apropriação mais favoráveis para a mão de obra, visando a sua atração. O tema tem muitas outras particularidades que não podemos desenvolver aqui. Engels apontou essas peculiaridades na ocupação da fronteira da Europa do Leste antes de Turner escrever 
o seu trabalho, mas os historiadores citados em seguida escreveram muito depois de Engels e já com pleno conhecimento do trabalho de Turner e numa perspectiva comparativa. ${ }^{20}$ Eis como Engels descreve a situação dos camponeses nas regiões recentemente ocupadas:

A colonização do Brandenburgo ${ }^{21}$ e da Silésia pelos colonos frísios, neerlandeses, saxões e francos da Renânia demonstra do modo mais evidente a absoluta necessidade, nesta época ainda, do agrupamento da Marca para a exploração agrícola, mesmo no caso da grande propriedade. A partir do século $\mathrm{XII}^{22}$, os camponeses foram distribuídos em aldeias nas terras senhoriais, de acordo com o direito alemão, isto é, segundo o velho direito da marca, na medida em que esta tivesse sido mantida nas propriedades dos senhores (Höffen). A cada um coube uma casa com quintal, uma parcela nos campos da aldeia - parcela designada pela sorte segundo o antigo costume -, e o direito de utilizar os bosques e os pastos, no mais das vezes situados nas florestas senhoriais, mais raramente numa marca particular. Tudo isso com direitos hereditários; a propriedade da terra ficava com o senhor ao qual os colonos deviam impostos e serviços determinados, também hereditários. Mas o caráter moderado desses encargos era tal que a condição dos camponeses era melhor do que em qualquer outra região da Alemanha; isto explica o porquê de não ter havido agitação nestes lugares quando estouraram as guerras camponesas. Eles pagariam caro esta defecção à causa que era também deles. ${ }^{23}$

O historiador espanhol Francisco Escamilla Vera, trabalhando em perspectiva comparativa, afirma que o desenvolvimento dos assentamentos com fins agrícolas em territórios de fronteira geralmente foi considerado um recurso para fortalecer estrategicamente esses territórios do ponto de vista geopolítico, militar ou de outra natureza.

A colonização da Dácia na época de Trajano poderia ser considerada como um exemplo. E o assentamento de camponeses bárbaros (germanos em sua maioria) em territórios "internos" do Império Romano no final da Idade Antiga poderia ser considerado outro exemplo de uma época algo posterior. Na Idade Média, a criação de algumas "Marcas" na Europa feudal cumpria também o mesmo objetivo... ${ }^{24}$

A Idade Média conheceu várias situações de colonização e fronteira (hoje em dia se fala de expansão e fechamento da fronteira na Idade Média). Entre estes movimentos expansionistas podemos citar: 1) o impulso dos alemães para o leste (citado por Engels) sob a direção dos Cavaleiros Teutônicos, dos príncipes e dos bispos cistercienses; 2) a formação dos feudos latinos no Levante nos séculos XI, XII e começos do XIII, depois das Cruzadas - Reino da Armênia, Condado de Edessa, Principado de Antióquia, Reino de Chipre, Reino de Jerusalém, Condado de Trípoli; 3) A Reconquista da Península Ibérica do século XI ao XV.

Para Archibald Lewis, do século XI a meados do século XIII a Europa Ocidental seguiu um padrão clássico de desenvolvimento de fronteira. A gradual expansão dos territórios sob o domínio dos europeus ocorreu em diversos pontos da fronteira. Estimulada pelas Cruzadas, houve a anexação de Chipre, Palestina e Síria, em seguida Creta e as ilhas do mar Egeu. Na Península Ibérica, a Reconquista retomou dos mouros as ilhas Baleares, a Sardenha e a Córsega. O sul da Itália e a Sićlia foram conquistados pelos Normandos. Na Europa do Noroeste, houve expansão dos ingleses em Gales, na Escócia e na Irlanda. Na Europa do Leste os alemães e escandinavos penetraram no Báltico e em terras ocupadas pelos eslavos. Mas, além disso, entre o ano 1000 e 
1250, houve um significativo avanço das fronteiras internas, e pântanos, florestas, terrenos alagadiços transformaram-se em terrenos de cultivo ou pastagem ${ }^{25}$.

Marc Bloch relata um episódio no povoamento de regiões afastadas do sul da França na Idade Média; trata-se do recrutamento para as "bastides" (aldeias fortificadas na fronteira): "no Languedoc, afirma, viram-se arautos percorrer o país apregoando aos quatro ventos a fundação de bastides"26.

Os estudos de Cláudio Sanchez-Albornoz assinalam que a Reconquista - a luta dos povos ibéricos contra os muçulmanos para expulsá-los da Península, que se prolongou do século VIII até 1492, quando as forças conjuntas de Castela e de Aragão entraram em triunfo no Alhambra - deixou de ser vista apenas como um combate político-militar e passou a ser vista também como um processo medieval de repovoamento e recolonização. Sanchez-Albornoz estudou a influência que exerceu sobre a população e as instituições de Castela a possibilidade de conquistar e povoar as terras sob o domínio dos muçulmanos. Seus estudos sublinham o caráter de fronteira deste movimento, quer dizer, o fato de tratar-se da ocupação e desenvolvimento de territórios "relativamente vazios" nas margens de uma sociedade em expansão. Esta situação particular proporcionou o gozo de liberdades políticas e oportunidades de ascensão social excepcionais para os mais audazes e eficientes guerreiros espanhóis e portugueses. Nestes séculos em que a fronteira cristão-muçulmana evoluiu em direção ao sul, os homens de Castela desenvolveram o que Sanchez Albornoz chamou de "alma da fronteira". A disposição de Sancho Pança em acompanhar D. Quixote em aventuras que trariam ricas recompensas, afirma, não era de modo nenhum excepcional - o sonho de ganhar boa fortuna com a expulsão dos mouros das ricas terras da Andaluzia era comum a muitos espanhóis ${ }^{27}$.

Slicher Van Bath estabeleceu um paralelo entre a técnica de recrutamento para as áreas de colonização da Alemanha Oriental e aquelas utilizadas para atrair imigrantes para a fronteira americana no século XIX.28

O arroteamento das terras novas, o movimento das Cruzadas e, sobretudo o desenvolvimento do comércio contribuíram para uma melhoria na situação do campesinato, em geral. Nas palavras de Engels:

De todo modo, eventos ocorridos em meados do século XIII trouxeram melhorias à condição dos camponeses; as Cruzadas haviam preparado o caminho. Muitos senhores que partiram nas Cruzadas deixaram seus camponeses expressamente livres. Outros morreram, foram arruinados, centenas de famílias nobres desapareceram e seus camponeses puderam assim alcançar a liberdade. Ajunte-se a isso que por causa das necessidades crescentes dos senhores, tornou-se muito mais importante para eles dispor das prestações dos camponeses do que das suas pessoas. A servidão dos começos da Idade Média, que se assemelhava de muitos modos à escravidão antiga, dava ao senhor direitos que foram constantemente perdendo valor. Ela desapareceu gradualmente e a condição de servo se equiparou à de um pagador de corveia.29 Dado que a exploração agrícola conservava seu caráter arcaico, os senhores de terra só podiam obter o aumento das suas rendas através da incorporação ao cultivo de terras novas e da instalação de novas aldeias. Mas para alcançar estes objetivos era preciso um acordo amigável com os colonos, quer estes pertencessem ao domínio ou fossem estrangeiros. Por isso encontramos, em quase todos os lugares, nesta época, estipulações muito precisas concernindo os encargos dos camponeses, a maior parte deles moderados, e também podemos constatar que os camponeses eram bem tratados, principalmente nos senhorios eclesiásticos. E, finalmente, a condição favorável dos colonos novos refletiu-se por sua vez na situação do camponeses sujeitos à corveia das terras vizinhas, tanto que estes, em 
toda a Alemanha do Norte, obtiveram a liberdade pessoal, continuando a pagar as prestações aos senhores de terras.30 Somente os camponeses eslavos e lituanoprussianos continuaram privados de liberdade. Mas tudo isso não devia durar muito. ${ }^{31}$

Em razão desses fatos explicitados por Engels, nas regiões de Grundherrschaft (a oeste do rio Elba), a economia camponesa se desenvolveu em direção ao mercado apesar de grande parte do excedente ser entregue ao senhor. Os camponeses mantiveram o controle (parcial) sobre a tecnologia e sobre os meios de produção e, quando a renda era paga em dinheiro, ganharam experiência nas atividades de mercado. Em contraste, à leste do rio Elba, a expansão das exportações de cereais para a Europa Ocidental no século XVI multiplicou os latifúndios, nos quais as operações de comercialização e produção foram concentradas nas mãos dos senhores. Esse fato levou paulatinamente a uma reviravolta na situação favorável dos camponeses do Leste.

\section{A segunda servidão}

Para dar conta dessa mudança na condição camponesa, Engels fez outra grande contribuição à história econômica, descrevendo o processo de refeudalização e às vezes de introdução de relações servis onde elas nunca haviam existido. Para descrever o fenômeno, em cartas para Marx, ele usou a expressão "segunda servidão" que acabou consagrada na história econômica, embora a expressão não apareça em $A$ Marca. ${ }^{32}$ Trata-se de um fenômeno marcante especialmente da história agrária do Leste Europeu, isto é, o fortalecimento do feudalismo na Europa quase no fim da Idade Média, sobretudo a partir da segunda metade do século XVI.

Economicamente, portanto, a servidão está vinculada na Europa Central e Oriental ao aparecimento e desenvolvimento, quase no fim da Idade Média da grande propriedade senhorial (Gutsherrschaft) baseada na corveia, à qual são submetidos os camponeses vinculados ao domínio e à pessoa do senhor.

O século XIV dividiu a Europa, grosso modo, em duas zonas. Aquela que corresponde mais ou menos à Europa Ocidental sem a península ibérica, na qual os camponeses continuaram firmes no caminho da emancipação e da diferenciação econômica (processo que só se completa no século XVI). E aquela onde houve a segunda servidão que corresponde à Europa Central e do Leste, inclusive a Rússia e também a península ibérica com grandes diferenças entre esta última e aquelas. Nestas áreas a emancipação ficou para o século XIX. Engels trata desta questão na seguinte passagem:

Nos séculos XIV e XV, o rápido crescimento das cidades levou-as a conhecerem a riqueza. As suas indústrias de arte e de luxo prosperaram, principalmente na Alemanha do Sul e às margens do Reno. A riqueza suntuosa do patriciado urbano perturbava o sono dos senhores rurais, com suas roupas feitas de pano grosseiro, suas refeições bem simplórias e seus móveis pesados e rústicos. Onde encontrar os esplendores urbanos? A bandidagem exercida nos caminhos tornava-se cada vez mais perigosa e infrutífera. E para comprar era preciso dinheiro. Ora, esse dinheiro somente o camponês podia fornecer. Em consequência disso o senhor exerceu mais pressão sobre os camponeses, e os encargos e as corveias foram aumentados; ele aplicou um novo e crescente zelo para 
tornar os camponeses livres novamente sujeitos às corveias, e os já submetidos às corveias em servos e, finalmente, transformou as terras comunais da marca em domínio senhorial. Nestes esforços os senhores e os nobres foram ajudados pelos juristas romanos que - pela aplicação de princípios jurídicos romanos às condições alemãs geralmente mal compreendidas - organizaram uma formidável confusão, conseguindo, porém que o senhor sempre saísse ganhando e que o camponês perdesse sempre. Os senhores eclesiásticos saíram-se bem de uma maneira mais simples: fabricaram documentos falsos nos quais os direitos dos camponeses foram diminuídos e seus encargos aumentados. Contra esta política de bandidagem, que foi a mesma dos soberanos, da nobreza e dos eclesiásticos, os camponeses se sublevaram em frequentes revoltas isoladas, desde o fim do século XV até que em 1525 a grande guerra camponesa se espalhou na Suábia, na Baviera, na Francônia, e penetrou até na Alsácia, no Palatinado, no Rheingau e na Turíngia. É deste momento que data o renascimento da predominância generalizada da servidão entre os camponeses alemães. Nas localidades onde a luta era intensa, todos os direitos que os camponeses tinham conservado foram odiosamente pisoteados; suas terras comuns foram convertidas em domínio senhorial e eles foram feitos servos. E os camponeses mais favorecidos do norte da Alemanha, que não participaram da luta receberam em agradecimento a queda sob o mesmo jugo e constrangimento, só que a sua opressão foi mais lenta. A servidão tal como existia entre os camponeses alemães foi introduzida na Prússia oriental, na Pomerânia, no Brandenburgo, na Silésia depois de meados do século XVI, no Sleswig-Holstein depois do fim do século XVI, e imposta aos camponeses de uma forma cada vez mais intensa. ${ }^{33}$

Como mostrou Witold Kula ${ }^{34}$, a lógica que presidia o funcionamento do feudalismo induzia senhores e camponeses a lutarem constantemente pelo excedente, pois dado o baixo grau de produtividade do sistema a única maneira do senhor ter seus rendimentos aumentados era, afora a incorporação de novas terras que já haviam se tornado escassas ("fechamento da fronteira"), diminuir a parcela do produto que cabia ao camponês. O renascimento do comércio, o crescimento das cidades e a ampliação dos mercados ofereceram novas oportunidades econômicas para os produtos agrícolas, interessando senhores e camponeses no desenvolvimento da produção. $\mathrm{O}$ recuo demográfico ocorrido no século XIV obrigou, até mesmo, a alteração das relações entre senhores e camponeses. Em muitas regiões, a drenagem de mão de obra foi tão grave que os senhores se viram obrigados a emancipar os servos para mantê-los no domínio. Embora de um modo geral isto significasse uma melhoria das condições de vida do camponês, nem sempre isto acontecia. ${ }^{35}$ Porém, nos fins do século XVI houve alteração nas relações camponês-senhorio. A situação pior foi a sofrida pelos camponeses da Europa do Leste, submetidos à segunda servidão. Os camponeses livres foram mergulhados em pelo menos três séculos de brutal servidão. As diferenças de destino entre os camponeses da Europa Ocidental e Oriental tiveram consequências de longo alcance no desenvolvimento posterior dessas duas regiões. É importante lembrar, como faz Engels, que o fim da servidão na Europa Oriental começa apenas com as Revoluções de 1848 e na Rússia só acontece em 1864.

A segunda servidão continua a interessar os historiadores. Produziram-se vários trabalhos que completaram de muitas formas o estudo pioneiro de Engels, e isso aconteceu particularmente nas regiões que foram mais afetadas por ela, isto é, na Rússia e na Europa Oriental. Na antiga União Soviética, a revista Voprosy Istorii (Questões de História) publicou inúmeros estudos históricos sobre 
o período da segunda servidão. Citamos acima o estudo de Serguei Skazkine, um dos mais densos e completos sobre o tema, publicado por aquela revista soviética e traduzido em Crítica Marxista ${ }^{\circ}$ 36. ${ }^{36}$ Igualmente importantes são os autores poloneses comentados por Pedro Costa Neto ${ }^{37}$.

As reflexões de Engels deram uma contribuição significativa para a melhor compreensão de um período rico em mudanças chamado de "crise do feudalismo" na história econômica. Suas observações sobre a transformação das formas de apropriação, com a introdução da propriedade privada plena na fase final do feudalismo levou a uma melhor compreensão das mudanças decorrentes na organização social que tiveram um papel fundamental na diversificação do campesinato e na formação das classes sociais no capitalismo.

\section{Referências}

BLOCH, Marc. "Pour une histoire comparée", Mélanges Historiques, tome I, S.E.V.P.E.N, Paris, Ecole Pratique des Hautes Etudes, 1963.

BLOCH, Marc. Les caractères originaux de l'histoire rurale française, 2 vols. Paris: Armand Colin, 1976, vol. I.

CALDAS, Marcos Jose de Araujo - Lutero, Müntzer e a Revolução do Homem Comum (1524-1524), in Intellectus, Ano XVII, n.2, p.1-25.

ENGELS, Friedrich - A marca, tradução de Cristiana Freitas, João Quartim de Moraes e Ligia Osorio Silva in Crítica Marxista, n.17, Rio de Janeiro: Ed. Revan, 2003, pp.147-163.

ENGELS, Friedrich - La guerre des paysans en Allemagne, tradução e introdução de Émile Bottigelli, Paris: Editons Sociales, 1974, disponível em:www.uqac.uquebec.ca/zone30/Classiques des sciences sociales/index.html.

ENGELS, Friedrich - A Origem da família, da Propriedade Privada e do Estado, Paris: Editions Sociales, 1954.

Escamilla Vera, Francisco - "Las fronteras conceptuales de un debate: el significado en Norteamérica del término "frontier", Biblio 3W. Revista Bibliográfica de Geografía y Ciencias Sociales, Universidad de Barcelona, n. 164, 7 de julho de 1999.

KNAUSS, Paulo (Org.), Oeste Americano, Quatro ensaios de história dos Estados Unidos da América de FJT, Niterói: EdUFF, 2004.

KULA, Witold - Théorie économique du système féodal, Paris: École Pratique des Hautes Études, 1970.

LEWIS, Archibald - "The closing of the European Frontier", Revista Speculum, XXXIII, 4 de outubro de 1958, p.475-476.

MARX, Karl - Os despossuídos, tradução de Nélio Schneider, São Paulo: Boitempo, 2017.

MARX, Karl - Capital, tradução de Samuel Moore e Edward Aveling, Londres: Lawrence \& Wishart, 1977.

MAYER, Gustav - Frederich Engels, A Biography, tradução de Gilbert e Helen Highet, London: Chapman \& Hall, Ltd., 1935.

OSORIO SILVA, Ligia - Notas introdutórias ao texto de F. Engels sobre a marca in Crítica Marxista, n.17, Rio de Janeiro: Ed. Revan, 2003, pp.141-146.

OSORIO SILVA, Ligia - Marx e a Gazeta Renana, in Adalberto Monteiro e Augusto Buonicore (Orgs.), Karl Marx, desbravar um mundo novo no século XXI, São Paulo: Anita Garibaldi/Fundação Maurício Grabois, 2018, pp.297-311.

RAUL, Virgínia - Sesmarias Medievais Portuguesas, Lisboa, s/e, 1946. 
SANCHEZ-ALBORNOZ, Claudio - "The frontier and Castilian Liberties" in Archibald Lewis \& Thomas McGann (org.), The New World looks at its history, Austin: University of Texas Press, 1963, p.27-46.

SKAZKINE, Sergey D. - Problemas fundamentais da "segunda servidão" na Europa Central e Oriental, tradução de Maria Loureiro, in Crítica Marxista N.36, São Paulo: Ed. Da UNESP, pp.63-92.

SLOTKIN, Richard - The Fatal Environment, The Myth of the Frontier in the Age of Industrialization, 1800-1890, University of Oklahoma Press, 1998.

VAN BATH, Slitcher - História Agrária da Europa Ocidental (500-1850), Lisboa: Presença, 1960.

VILAR, Pierre - Economia, Derecho, Historia, Barcelona: Ariel, 1983.

\section{Notas}

1 Professora titular aposentada do Instituto de Economia da Unicamp. Graduada em Ciências Sociais (UFRJ/1966), mestre em Sociologia (UNICAMP/1977) e doutora em Ciências Sociais (PUC-SP/1991). Professora do Departamento de sociologia do IFCH-UNICAMP em 1974, transferindo-se para o Instituto de Economia em 1989. Realizou pós-doutorado na Universidade de Paris IV (1993) na área de História do Brasil e é Livre-docente em História Econômica pelo Instituto de Economia da UNICAMP (2001). Currículo Lattes: http://lattes.cnpq.br/5918628000357501 Orcid: https://orcid.org/0000-0003-3925-3286 E-mail: ligiasilva@unicamp.br

2 Quando escreve sobre as guerras camponesas, Engels não tinha ainda 30 anos, mas já havia elaborado junto com Marx os fundamentos do materialismo histórico na Ideologia Alemã (1846) e o Manifesto Comunista (1848). Além disso ambos tinham acabado de passar por uma experiência revolucionária concreta.

${ }^{3}$ Revista de economia política dirigida por Karl Marx de curta duração (outono de 1849 a outono de 1850). No original, o artigo chamava-se Der deutsche Bauernkrieg. Utilizamos a versão francesa, La guerre des paysans en Allemagne, tradução e introdução de Émile Bottigelli, Paris: Editons Sociales, 1974, disponível em:www.uqac.uquebec.ca/zone30/Classiques des sciences sociales/index.html.

4 "Os artigos fundamentais e justos de todo o campesinato, antecedidos por aqueles relativos às autoridades espirituais e leigas, em relação às quais eles se julgam incomodados”, esse é o título do opúsculo, Coleção dos camponeses da Suábia Superior, 1525. A íntegra dos artigos em alemão e traduzidos para o português está em Marcos Jose de Araujo Caldas, Lutero, Müntzer e a Revolução do Homem Comum (1524-1524), in Intellectus, Ano XVII, n.2, p.10-22.

${ }^{5}$ Emile Bottigelli, Introduction, in F. Engels, La guerre... ob.cit. p.9.

${ }^{6}$ La guerre des paysans em Allemagne, ob. cit., p.110. Tradução de L.Osorio Silva.

7 Idem p. 98. Gustav Mayer, Frederich Engels, A Biography, Tradução de Gilbert e Helen Highet, London: Chapman \& Hall, Ltd., 1935, p.117-118.

8 Engels utilizou-se do livro de Wilhelm Zimmermann, História Geral da Grande Guerra Camponesa, publicado na Alemanha em 1841/42, baseado em grande documentação primária.

${ }^{9}$ Émile Bottigelli, Introdução, in F. Engels, La guerre des paysans..., ob. cit., p. 9.

10 Ver Marcos Jose de Araujo Caldas, ob. cit. p. X

${ }^{11}$ Frederich Engels, A marca, tradução de Cristiana Freitas, João Quartim de Moraes e Ligia Osorio Silva in Crítica Marxista, n.17, Rio de Janeiro: Ed. Revan, 2003, pp.147-163.

${ }^{12}$ Ver Ligia Osorio Silva, Notas introdutórias ao texto de F. Engels sobre a marca in Crítica Marxista, ob.cit. , p. 141.

13 Pierre Vilar, Economia, Derecho, Historia, Barcelona: Ariel, 1983, p.109.

14 Ver Karl Marx, Os despossuidos, Tradução de Nélio Schneider, São Paulo: Boitempo, 2017 e L. Osorio Silva, Marx e a Gazeta Renana, in Adalberto Monteiro e Augusto Buonicore (Orgs.), Karl Marx, Desbravar um mundo novo no século XXI, São Paulo: Anita Garibaldi/Fundação Maurício Grabois, 2018, pp.297-311.

15 O Capital, vol I, Parte VII, Cap. XXVII, pp.676-681.

${ }^{16}$ Sergey D. Skazkine, Problemas fundamentais da "segunda servidão" na Europa Central e Oriental, in Crítica Marxista N.36, São Paulo: Ed. Da UNESP, p.64-66.

17 Em determinado momento do seu desenvolvimento os senhores também fizeram parte da marca, complicando ainda mais a apreensão do seu significado.

${ }^{18}$ Engels, A marca, ob. cit., p.148. Ver também Marc Bloch, "Pour une histoire comparée”, Mélanges Historiques, tome I, S.E.V.P.E.N, Paris, Ecole Pratique des Hautes Etudes,1963, p.39.

19 Van Bath, História Agrária da Europa Ocidental (500-1850), Lisboa: Presença, 1960, p. 161.

${ }^{20}$ Remeto o leitor ao trabalho de Turner em Paulo Knauss (Org.), Oeste Americano, Quatro ensaios de história dos Estados Unidos da América de FJT, Niterói: EdUFF, 2004 e para uma visão crítica a Richard Slotkin, The Fatal Environment, The Myth of the Frontier in the Age of Industrialization, 1800-1890, University of Oklahoma Press, 1998.

21 Anotação de Engels "da Prússia oriental”. 
22 Anotação de Engels "do século XII ao XV".

${ }^{23}$ F. Engels, A marca, ob.cit. p.158.

${ }^{24}$ Francisco Escamilla Vera, "Las fronteras conceptuales de un debate: el significado en Norteamérica del término "frontier", Biblio 3W. Revista Bibliográfica de Geografia y Ciencias Sociales, Universidad de Barcelona, n. 164, 7 de julho de 1999, p.7.

${ }_{25}$ Archibald Lewis, “The closing of the European Frontier”, Revista Speculum, XXXIII, 4 de outubro de 1958, p.475-476.

${ }^{26}$ Marc Bloch, Les caractères originaux de l'histoire rurale française, 2 vols. Paris: Armand Colin, 1976, vol. I, p.15.

27 "The frontier and Castilian Liberties" in Archibald Lewis \& Thomas McGann (org.), The New World looks at its history, Austin: University of Texas Press, 1963, p.27-46. A Reconquista em Portugal teve algumas peculiaridades. A historiadora Virgínia Rau chama a atenção para a predominância de formas de apropriação distintas da clássica enfiteuse (tipicamente feudal) nas regiões retomadas dos mouros. A presúria, ocupação e posse à mão armada predominou durante este período. Sesmarias Medievais Portuguesas, Lisboa, s/e, 1946.

${ }^{28}$ História Agrária da Europa Ocidental (500-1850), ob. cit., p.158.

${ }^{29}$ Note-se que o pagador de corveia pode ser ou não servo da gleba.

30 A transformação da renda trabalho em renda dinheiro é aquilo que se chama de comutação na história econômica.

31 F. Engels, A marca, ob. Cit., p.159.

32 As ideias de Marx e de Engels sobre a "segunda servidão" encontram-se nas suas cartas dos dias 15, 16 e 22 de dezembro de 1882, reproduzidas em Engels, A Origem da família, da Propriedade Privada e do Estado, Paris: Editions Sociales, 1954, p.299-301.

${ }^{33}$ Engels, A marca, ob.cit. p.159.

34 Witold Kula, Théorie économique du système féodal, tradução revista pelo autor, Paris: École Pratique des Hautes Études-Sorbonne, 1970, pp.28-43.

$35 \mathrm{Nem}$ sempre a situação de homem livre representava um real avanço para o trabalhador porque às obrigações que atavam o camponês ao seu senhor, correspondiam certas obrigações deste para com os seus homens, sobretudo o que modernamente chamamos de "garantia no emprego".

36 A tradução de Crítica Marxista baseou-se na versão francesa de1970, publicada da revista Recherches Internacionales à la lumière du marxisme (n ${ }^{\circ}$ 63-64), o artigo Problemas fundamentais da "segunda servidão" na Europa Central e Oriental, pp.63-92.

${ }^{37}$ Sobre a Polônia ver Pedro Leão da Costa Neto, Comentários bibliográficos sobre a segunda servidão na Polônia, Crítica Marxista, ibidem, pp. 93-100.

Recebido em: 10.2020

Aprovado em: 10.2020 